\title{
A betegbiztonságot támogató szervezeti kultúra változása a hazai akkreditációs programot tesztelő intézményekben
}

\author{
Lám Judit dr. ${ }^{1}$ - Merész Gergő ${ }^{1,2}$ - Bakacsi Gyula dr. ${ }^{1}$ - Belicza Éva dr. ${ }^{1}$ \\ Surján Cecília ${ }^{1,2}$. Takács Erika dr. ${ }^{1}$ \\ Semmelweis Egyetem, ${ }^{1}$ Egészségügyi Menedzserképző Központ, ${ }^{2}$ Doktori Iskola, Budapest
}

\begin{abstract}
Bevezetés: Magyarországon 2012-ben indult az egészségügyi ellátószervezetek akkreditációs programjának fejlesztése, amelynek célja az egészségügyi ellátás biztonságának növelése, eredményességének, hatékonyságának javítása. Célkitüzés: A vizsgálat célja az akkreditációs standardok hatására történő szervezeti változások felmérése a projekt tesztelésében részt vevő intézményekben. Módszer: Hét önkéntes intézményben vizsgálták a szervezeti kultúra változását nemzetközileg validált kérdő́iv segítségével. A vizsgálatot két körben, az akkreditációs program bevezetésének kezdete elótt és egy évvel később, standardok megismerése, gyakorlatba ültetésének elkezdése után végezték el. A kérdőíveket leíró statisztikai elemzésekkel és logisztikus regressziós modellekkel vizsgálták. Eredmények: A kórházak körében szignifikáns $(\mathrm{p}<0,05)$ pozitív változást mutattak a szervezeti tanulás, folyamatos fejlődés, a nyílt kommunikáció és a csapatmunka a szervezeti egységben dimenziók, az önálló járóbeteg-szakrendelők körében pedig az általános felfogás a betegbiztonságról és a betegbiztonság szervezeti egységen belüli észlelése dimenziók. Következtetések: A vizsgált intézményekben a szervezeti kultúra még fejlesztésre szorul, de az észlelt pozitív változások a betegbiztonságot elősegítő irányba mutatnak. Orv. Hetil., 2016, 157(42), 1667-1673.
\end{abstract}

Kulcsszavak: betegbiztonság, betegbiztonságot támogató szervezeti kultúra, szervezeti kultúra, akkreditáció

\section{Changing of the patient safety culture in the pilot institutes of the Hungarian accreditation program}

\begin{abstract}
Introduction: The accreditation system for health care providers was developed in Hungary aiming to increase safety, efficiency, and efficacy of care and optimise its organisational operation. Aim: The aim of this study was to assess changes of organisational culture in pilot institutes of the accreditation program. Method: 7 volunteer pilot institutes using an internationally validated questionnaire were included. The impact study was performed in 2 rounds: the first before the introduction of the accreditation program, and the second a year later, when the standards were already known. Data were analysed using descriptive statistics and logistic regression models. Results: Statistically significant $(\mathrm{p}<0.05)$ positive changes were detected in hospitals in three dimensions: organisational learning - continuous improvement, communication openness, teamwork within the unit while in outpatient clinics: overall perceptions of patient safety, and patient safety within the unit. Conclusions: Organisational culture in the observed institutes needs improvement, but positive changes already point to a safer care.
\end{abstract}

Keywords: patient safety, safety culture, organizational culture, accreditation

Lám, J., Merész, G., Bakacsi, Gy., Belicza, É., Surján, C., Takács, E. [Changing of the patient safety culture in the pilot institutes of the Hungarian accreditation program]. Orv. Hetil., 2016, 157(42), 1667-1673.

(Beérkezett: 2016. július 8.; elfogadva: 2016. augusztus 10.)

\section{Rövidítések}

AHRQ = Agency for Health Care Research and Quality; BELLA = BetegELLátók Akkreditációja a biztonságos betegel- látásért; HSOPSC $=$ Hospital Survey on Patient Safety Culture (kórházi betegbiztonsági kultúra felmérés); PDCA = Plan-DoCheck-Act (tervezés-cselekvés-ellenőrzés-visszacsatolás) 
Magyarországon a betegellátás biztonságának javítása érdekében 2012-ben indult átfogó program európai uniós források bevonásával. A BELLA (BetegELLátók Akkreditációja a biztonságos betegellátásért) elnevezésú rendszer célja az egészségügyi ellátás biztonságának növelése, az ellátás eredményességének és hatékonyságának javítása, a szervezeti múködés áttekintése és fejlesztése és mindezek érdekében a szervezeti kultúra befolyásolása a betegbiztonság irányában.

A program kidolgozási fázisának második évében, 2014 folyamán 10 intézményben teszteltük a rendszer alapját képező szabályozókat: az elkészült BELLA-standardokat. A pilot program keretében a gyakorlati alkalmazásra való felkészítés intézménytípustól függetlenül egységes módszertan alapján zajlott oktatások és konzultációk segítségével. A képzések során létrehozott belső koordinátori rendszer biztosította azt, hogy minden, a standardokban érintett munkatárs megértse saját felelősségét és feladatát, és a szükséges változások megvalósulhassanak. A standardok szerinti múködés kialakítását az intézményekben belső munkatársakból álló teamek végezték, amelyekben különböző szervezeti egységben dolgozó, különböző munkakörű kollégák munkálkodtak közösen.

Már a projekt tervezésekor felmerült az igény, hogy felmérjük az akkreditációs programmal elért eredményeket annak érdekében, hogy ezek figyelembevételével születhessenek a további fejlesztések, egészségpolitikai döntések. Az első hatásvizsgálati kutatást, amely az akkreditációs standardok hatására történő szervezeti kultúraváltozások felmérését tűzte ki célul, munkacsoportunk az erre önként jelentkező 7, a pilot projektben részt vevő intézmény bevonásával indította el.

Szervezeti kultúra alatt az egy szervezetben dolgozók „közösen értelmezett előfeltevéseinek, értékeinek, meggyőződéseinek és hiedelmeinek rendszerét" értjük [1]. A szervezeti kultúra jelentősen befolyásolja a szervezet tagjainak viselkedését, hiszen az egy szervezeti kultúrához tartozók az így kialakult közös gondolkodási keretet és értékrendet érvényesnek fogadják el, követik és a szervezet új tagjai számára is átadják úgy, mint a problémák megoldásának lehetséges mintáit, és mint kívánatos gondolkodás- és magatartásmódot [1].

A szervezetek bármely típusára igaz, hogy a múködésük során fellépő veszélyek és kockázatok felismerésének és azok eredményes kezelésének kedvez, ha a szervezetben biztonságot támogató szervezeti kultúrát sikerül kialakítani és fenntartani. Egészségügyi intézményekre értelmezve mindez a betegbiztonságot támogató szervezeti kultúra jelenlétét feltételezi. A legismertebb definíció szerint a betegbiztonságot támogató szervezeti kultúra a szervezet általános kultúrájának egy specifikus aspektusa: az egyéni és csoportértékek, attitüdök, felfogások, viselkedési minták és kompetenciák összessége, amelyek meghatározzák egy szervezetben a betegbiztonságot támogató intézkedésekhez kapcsolódó viszonyrendszert és szakértelmet [2]. A betegbiztonságot támo- gató szervezeti kultúrájú intézmények a kölcsönös bizalmon alapuló kommunikációval, a biztonság jelentőségét elismerő közös gondolkodásmóddal és az eredményesen alkalmazott megelőző intézkedésekkel jellemezhetők [3]. Az ilyen intézményekben a munkatársak szóvá teszik a kockázatos szituációkat és magatartásformákat, követik a biztonságos múködés szempontjából kritikus szabályokat, és a múködés biztonságosságát helyezik előtérbe a kibocsátás volumenével szemben [4]. Egy betegbiztonság javítását célul kitűző egészségügyi szolgáltató számára fontos ismerni a szervezeten belül kialakult betegbiztonságot támogató szervezeti kultúra aktuális jellemzőit és meghatározni a szervezeti kultúra azon területeit, amelyek fejlesztése a kívánt eredmény eléréséhez szükségesek [2].

A szervezeti kultúra általános dimenzióinak mérésére számos kérdőívet fejlesztettek és alkalmaznak az egészségügyi szervezetekben [5]. A betegbiztonság és szervezeti kultúra kapcsolatának felismerése segítette elő a speciális, a betegbiztonságot támogató szervezeti kultúra kvantitatív értékelésére alkalmas kérdőívek kialakítását és alkalmazását [6].

Jelen közleményünk célja az akkreditációs pilot projekt hatására bekövetkező szervezetikultúra-változások első eredményeinek bemutatása, értelmezése.

\section{Módszer}

Hatásvizsgálatunk keretében a kutatásban részvételt vállaló hét vizsgálati helyszínen, négy kórházban és három önálló szakrendelőben mértük a szervezeti kultúra változását a HSOPSC (Hospital Survey on Patient Safety Culture, kórházi betegbiztonsági kultúra felmérés) [7] kérdőív segítségével, amelyet az AHRQ (Agency for Health Care Research and Quality) fejlesztett [6]. A kérdóívet számos kutatási programban alkalmazzák a betegbiztonságot támogató szervezeti kultúra felmérésére, időbeli alakulásának követésére, különböző országokban végzett szervezetikultúra-kutatások eredményeinek öszszevetésére [8]. A kérdőív 12 dimenzióba rendezhető 42 kérdés segítségével méri fel a kórházi személyzet attitűdjét és véleményét a betegbiztonsággal, -ellátással összefüggő hibákkal és jelentési tevékenységgel kapcsolatban. A kérdések zöménél a válaszok ötfokozatú skálák segítségével, a megfelelő érték jelölésével kerülnek megadásra. A kérdőív két kimeneti mutatóra is rákérdez, így a betegbiztonság általános helyzetének megítélésére a válaszadó szervezeti egységében, valamint az elmúlt 12 hónapban jelentett események számára. Néhány háttéradat megadását is kéri a válaszadóktól, például a munkakört és a szervezetben eltöltött időt $[7,9]$.

Az angol nyelvű kérdőívet két szakértőnk fordította le magyarra egymástól függetlenül. A fordításokat két további szakértő bevonásával vetették össze, a végleges változat konszenzus alapján született. A magyar nyelvú kérdőívet egészségügyben dolgozókkal teszteltük érthetőség, egyértelmúség szempontjából, ezek alapján nyerte 
el minimális bővítésekkel a kérdőív a végleges formáját. Az eredetileg kórházakra kifejlesztett kérdőívet járóbeteg-szakrendelőkre is adaptáltuk az átadások és átmenetek dimenzió csak fekvőbeteg-ellátásban értelmezhető négy kérdésének átfogalmazásával.

A kérdőívek kitöltése két körben, azonos módszerekkel zajlott. Az első kör során, 2014 tavaszán az akkreditációs pilot projekt indulása előtti betegbiztonsági szervezeti kultúrát vizsgáltuk. $\mathrm{Az}$ ismételt felmérést ( „második kör”) a felkészítési időszak lezárását követően 2015 tavaszán végeztük. A felmérésbe a hatásvizsgálatban részt vevő szervezetek minden dolgozóját bevontuk. A kitöltés önkéntes és anonim volt. Az összegyúlt válaszokat MS Excel állományba rögzítettük, az adatbevitel minőségét ellenőriztük és elvégeztük a szükséges adattisztítást. A hiányzó vagy nem egyértelmű válaszokat tartalmazó kérdőíveket az adott dimenzió elemzésekor nem vettük figyelembe. A kérdőívek feldolgozását két csoportban, külön a kórházakra és külön a járóbetegszakrendelőkre vonatkozóan végeztük.

A kérdésekből 12 dimenziót hoztunk létre a kérdőívhez kapcsolódó útmutató [9] alapján. A dimenziókat jellemző dichotóm (0 vagy l értékű) változókat határoztunk meg. Értéke 1, ha a dimenzióhoz tartozó kérdésekre adott válaszok mindegyike a két legkedvezőbb skálaértéket vette fel az ötfokozatú skálán [9]. A szervezeti kultúrára vonatkozó további két kérdést is dichotóm változókká alakítottuk, így a betegbiztonság értékelését az ötfokozatú skálán a dimenziókhoz hasonló módon kódoltuk. A jelentett nem várt események számára vonatkozó kérdésnél a változó 1-es értéket vett fel, ha a válaszadó jelentett legalább egy eseményt, 0-át pedig, ha egyet sem. Az így kialakított 14 dimenziót vagy kérdést jellemző változók l-es értékének aránya adja a betegbiztonság szempontjából pozitív válaszok arányát.

A szervezeti kultúrát jellemző 12 dimenziót és a további kettő, egy-egy kérdésből álló változót a nyers mutatók meghatározása mellett logisztikus regressziós modellekkel elemeztük. A függő változó az adott dimenziót jellemző dichotóm változó, a beemelt független változók: a kérdezés köre (első vagy második), a válaszadó kora, neme, intézménye, munkaköre, szervezeti egységének típusa, pozíciója a szervezeti hierarchiában, mióta dolgozik az intézményben és heti hány órában. A második körre történő változást a logisztikus regressziós modellekkel becsült esélyhányadossal értékeltük.

Az adatok elemzését az IBM SPSS statisztikai szoftver 22 -es verziójával végeztük el. Szignifikanciaszintként a $\mathrm{p}<0,05$ értéket választottuk.

\section{Eredmények}

Összesen 5639 kérdőívet osztottunk ki. A kitöltési arány az első körben 54-56\%, a másodikban 46-49\% volt (1. táblázat). A kérdőívet kitöltők főbb jellemzőit az 1 . táblázat tartalmazza.
1. táblázat |A két kitöltési kör általános jellemzői

\begin{tabular}{|c|c|c|c|c|c|}
\hline & \multicolumn{2}{|c|}{ Kórházak } & \multicolumn{2}{|c|}{$\begin{array}{l}\text { Önálló } \\
\text { járóbeteg- } \\
\text { szakrendelők }\end{array}$} \\
\hline & & \multicolumn{2}{|c|}{ Kérdezési kör } & \multicolumn{2}{|c|}{ Kérdezési kör } \\
\hline & & Első & Második & Első & Második \\
\hline & Kiosztott kérdőívek száma & 2217 & 2296 & 569 & 557 \\
\hline & Válaszadási arány (\%) & 56 & 49 & 54 & 46 \\
\hline \multirow{7}{*}{ 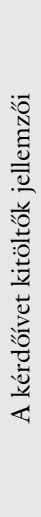 } & Nők aránya (\%) & 76,4 & 77,8 & 85,4 & 86,5 \\
\hline & Életkor >40 év (\%) & 59,1 & 55,2 & 80,4 & 78,1 \\
\hline & $\begin{array}{l}\text { A szervezetben eltöltött idő } \\
<6 \text { év }(\%)\end{array}$ & 41,3 & 40 & 36,7 & 38,7 \\
\hline & $\begin{array}{l}\text { A szervezetben eltöltött idő } \\
>20 \text { év }(\%)\end{array}$ & 18,3 & 16,6 & 18,5 & 19,5 \\
\hline & $\begin{array}{l}\text { A szervezetben heti 40-59 } \\
\text { órát dolgozók (\%) }\end{array}$ & 69,8 & 69,5 & 52,9 & 50,6 \\
\hline & $\begin{array}{l}\text { Ápolók/asszisztensek } \\
\text { aránya (\%) }\end{array}$ & 48,4 & 51,7 & 43,5 & 47,4 \\
\hline & $\begin{array}{l}\text { Vezető beosztásúak aránya } \\
(\%)\end{array}$ & 18,8 & 16,5 & 27,3 & 28,0 \\
\hline
\end{tabular}

A kiinduló felmérési körben a kórházak esetében egyetlen dimenziónál sem haladta meg a pozitív válaszok aránya az 50\%-ot (2. táblázat). A pozitív válaszok aránya a csapatmunka a szervezeti egységben és a betegbiztonság osztályozása dimenzióknál 40 és $50 \%$ között volt, amelyek a nyers adatok alapján enyhén növekedtek is a második körös felmérésre. A nyers adatok alapján párszázalékos emelkedés volt a pozitív válaszok arányában még a szervezeti tanulás, folyamatos fejlődés, a visszajelzések és kommunikáció a hibákról, valamint a nyílt kommunikáció dimenziókban. Az utóbbi dimenzióról még fontos megjegyezni, hogy a legalacsonyabbak között volt a pozitív válaszok aránya, 11,3\%-ról emelkedett 14,9\%-ra. A dimenziók közül egy esetben, a felső vezetés támogatása betegbiztonsági kérdésekben dimenziót jellemző változó esetében volt tapasztalható gyenge negatív elmozdulás.

A két felmérésnél a válaszadók összetételében mutatkozó különbségek kiküszöbölésére alkalmazott többváltozós logisztikus regresszió eredményei, a dimenziónként meghatározott esélyhányadosok és konfidenciaintervallumaik láthatóak a kórházak esetében az 1 . ábrán. Az első és második körös felmérés között a pozitív válaszok arányának növekedése statisztikailag szignifikáns $(\mathrm{p}<0,05)$ volt a szervezeti tanulás, folyamatos fejlődés, a nyílt kommunikáció, valamint a csapatmunka a szervezeti egységben dimenziókban. A pozitív válaszok arányának csökkenését mutató dimenzióban nem volt statisztikailag szignifikáns az elmozdulás.

Az önálló járóbeteg-szakrendelőknél a kórházaktól eltérően már az első körös felmérésben több dimenzió esetében is meghaladta a pozitív válaszok aránya az $50 \%$-ot (2. táblázat). Ugyanakkor a nyílt kommunikáció dimen- 
2. táblázat |A pozitív válaszok aránya dimenziónként és intézménytípusonként, nyers mutatók

\begin{tabular}{|c|c|c|c|c|}
\hline \multicolumn{5}{|c|}{ Pozitív válaszok aránya } \\
\hline \multirow{2}{*}{$\begin{array}{l}\text { Dimenziók } \\
\text { (a dimenziókon belüli kérdések száma) }\end{array}$} & \multicolumn{2}{|c|}{ Kórházak } & \multicolumn{2}{|c|}{ Önálló járóbetegszakrendelők } \\
\hline & Első kör & Második kör & Első kör & Második kör \\
\hline Csapatmunka szervezeti egységen belül (4) & $41,3 \%$ & $45,3 \%$ & $68,7 \%$ & $74,8 \%$ \\
\hline Felettesek betegbiztonságot támogató elvárásai és cselekedetei (4) & $28,8 \%$ & $29,9 \%$ & $43,3 \%$ & $44,5 \%$ \\
\hline Szervezeti tanulás, folyamatos fejlesztés (3) & $28,5 \%$ & $33,0 \%$ & $43,0 \%$ & $44,1 \%$ \\
\hline Menedzsment támogatása a betegbiztonsághoz (3) & $31,7 \%$ & $28,8 \%$ & $73,8 \%$ & $77,2 \%$ \\
\hline A betegbiztonság általános észlelése (4) & $19,4 \%$ & $20,9 \%$ & $44,6 \%$ & $49,8 \%$ \\
\hline Hibákkal kapcsolatos visszajelzés és kommunikáció (3) & $33,3 \%$ & $36,6 \%$ & $56,2 \%$ & $57,3 \%$ \\
\hline Kommunikáció nyíltsága (3) & $11,3 \%$ & $14,9 \%$ & $11,3 \%$ & $18,3 \%$ \\
\hline Események jelentésének gyakorisága (3) & $47,8 \%$ & $47,5 \%$ & $46,7 \%$ & $51,2 \%$ \\
\hline Csapatmunka szervezeti egységek között (4) & $16,7 \%$ & $17,3 \%$ & $48,4 \%$ & $48,6 \%$ \\
\hline Személyzettel való ellátottság (4) & $3,5 \%$ & $2,8 \%$ & $14,0 \%$ & $10,1 \%$ \\
\hline Betegátadás és -áthelyezés (4) & $16,0 \%$ & $15,0 \%$ & $38,8 \%$ & $43,4 \%$ \\
\hline Nem büntető reagálás a hibákra (3) & $10,4 \%$ & $10,2 \%$ & $15,8 \%$ & $20,6 \%$ \\
\hline A betegbiztonság értékelése a szervezeti egységben (1) & $44,2 \%$ & $48,1 \%$ & $72,3 \%$ & $79,5 \%$ \\
\hline Események jelentése (1) & $25,6 \%$ & $24,1 \%$ & $12,1 \%$ & $11,9 \%$ \\
\hline
\end{tabular}

Fogalomjegyzék

\begin{tabular}{|c|c|}
\hline Fogalom & Meghatározás \\
\hline Nemkívánatos esemény & $\begin{array}{l}\text { Az ellátás nyújtásához köthető, az elvégzett vagy elmaradt tevékenység következtében fellépő betegkárosodás } \\
\text { és nem a betegségből eredő komplikáció. }\end{array}$ \\
\hline $\begin{array}{l}\text { Egészségügyi szolgáltatók } \\
\text { akkreditációja }\end{array}$ & $\begin{array}{l}\text { Az adott ellátási formára specifikus standardok szerinti működés elismerése, amely az egészségügyi szolgáltatók } \\
\text { önértékelésén és külső kollegiális felülvizsgálatán keresztül valósul meg. }\end{array}$ \\
\hline Akkreditációs standard & Az egészségügyi szolgáltató betegellátással kapcsolatos, napi múködését leíró szabályozó. \\
\hline Majdnem hiba (near miss) & $\begin{array}{l}\text { Súlyos hiba vagy botlás, ami potenciálisan nemkívánatos eseményt okozhat, de ez véletlenül vagy mert időben } \\
\text { észreveszik, nem következik be. Másképpen potenciális nemkívánatos eseménynek is hívják. }\end{array}$ \\
\hline Leadership & $\begin{array}{l}\text { A leadershipet a vezetői tevékenység egy olyan elemeként határozhatjuk meg, amely } \\
\text { - a szervezeti erőforrások közül kitüntetetten az emberi erőforrással foglalkozik (a vezető és beosztottjai } \\
\text { közötti kapcsolat módjára keresi a választ); } \\
\text { - annak a képességét jelenti, hogy hogyan tudja a vezető a szervezet tagjait a szervezeti célok megvalósítására } \\
\text { befolyásolni, mozgósítani. } \\
\text { A leadership lényege tehát az egyéni motivációkból eredeztethető személyes célok és a szervezeti célok } \\
\text { összekapcsolása. Az egyik a másiknak feltétele, az egyik célelérés nem mehet a másik cél rovására. }\end{array}$ \\
\hline PDCA-ciklus & $\begin{array}{l}4 \text { egymást követő fázisból (Plan-Do-Check-Act) felépülő, ismétlődő ciklus, amely a folyamatos } \\
\text { minőségfejlesztés alapmodellje. }\end{array}$ \\
\hline Betegátadás & $\begin{array}{l}\text { Szakmai felelősség és számonkérhetőség átadása az ellátás egy vagy több aspektusában, egy betegre vagy } \\
\text { betegcsoportra vonatkozóan, egy másik személynek vagy szakemberek csoportjának, ideiglenesen vagy } \\
\text { véglegesen. }\end{array}$ \\
\hline
\end{tabular}

zióban a kórházakéhoz hasonló nagyon alacsony arány figyelhető meg. A 14 dimenzió közül 8 esetében volt tapasztalható enyhe növekedés a pozitív válaszok arányában, azaz ezeknél az intézményeknél még szembetünőbb az egyéves pilot projekt időszakában a változás iránya. Egyedül a személyzettel való ellátottság dimenzióban adott pozitív válaszok aránya csökkent jelentősebben, pár százalékkal.

Az önálló járóbeteg-szakrendelőknél a többváltozós logisztikus regresszió alapján (2. ábra) szignifikáns pozitív változás volt az általános felfogás a betegbiztonságról és a betegbiztonság szervezeti egységen belüli észlelése dimenziók megítélésében. A pozitív válaszok arányának csökkenését mutató dimenzióban nem volt statisztikailag szignifikáns a változás.

\section{Megbeszélés}

Eredményeink szerint a betegbiztonságot támogató szervezeti kultúra a kutatásban részt vevő intézményekben még gyenge, fejlesztésre szorul. A szakirodalom alapján az egyes dimenziókra adott válaszokból képzett 


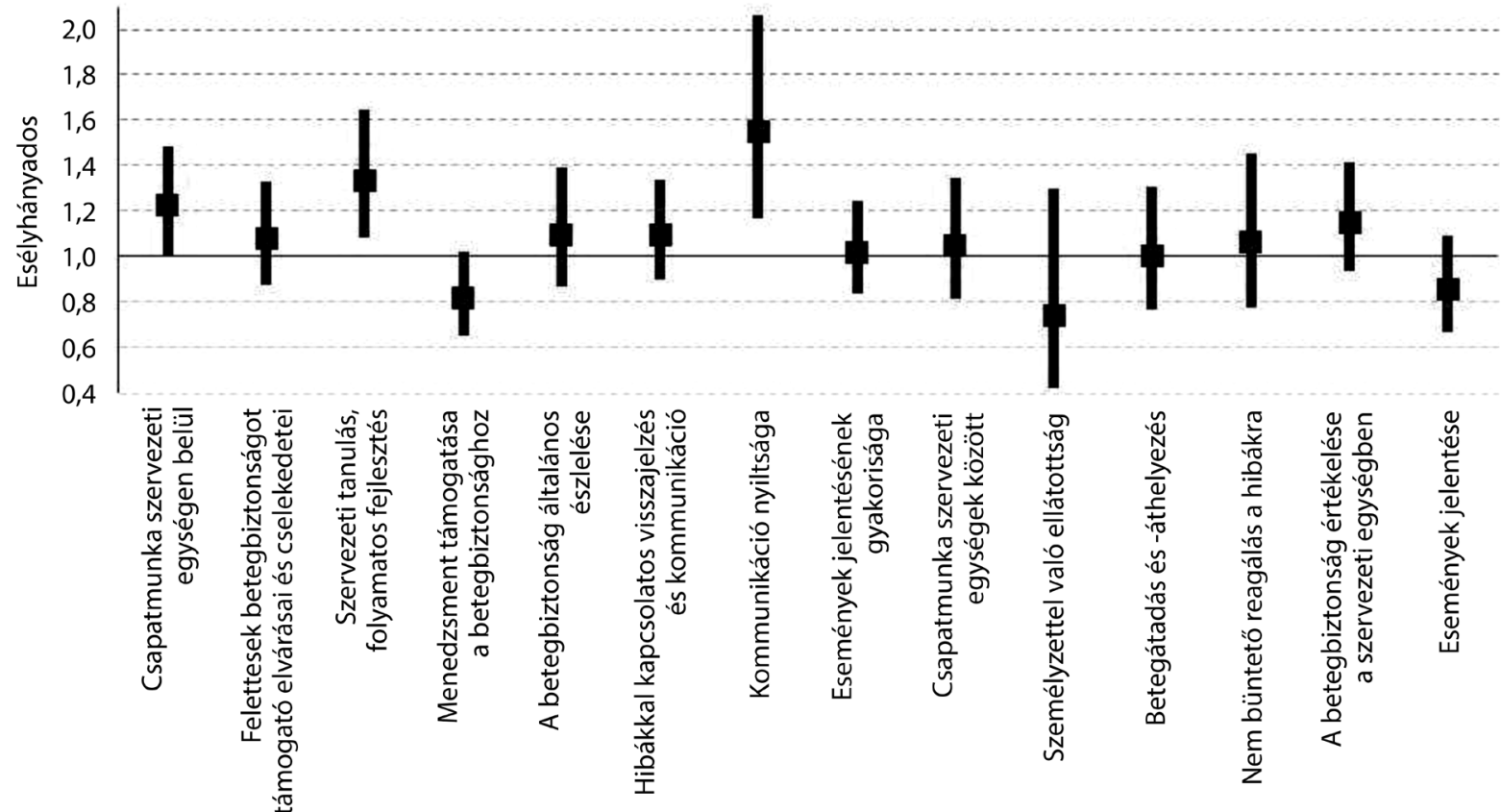

l. ábra | A szervezeti kultúra dimenziókat jellemző változók esélyhányadosai (és 95\%-os CI) a kórházak esetében

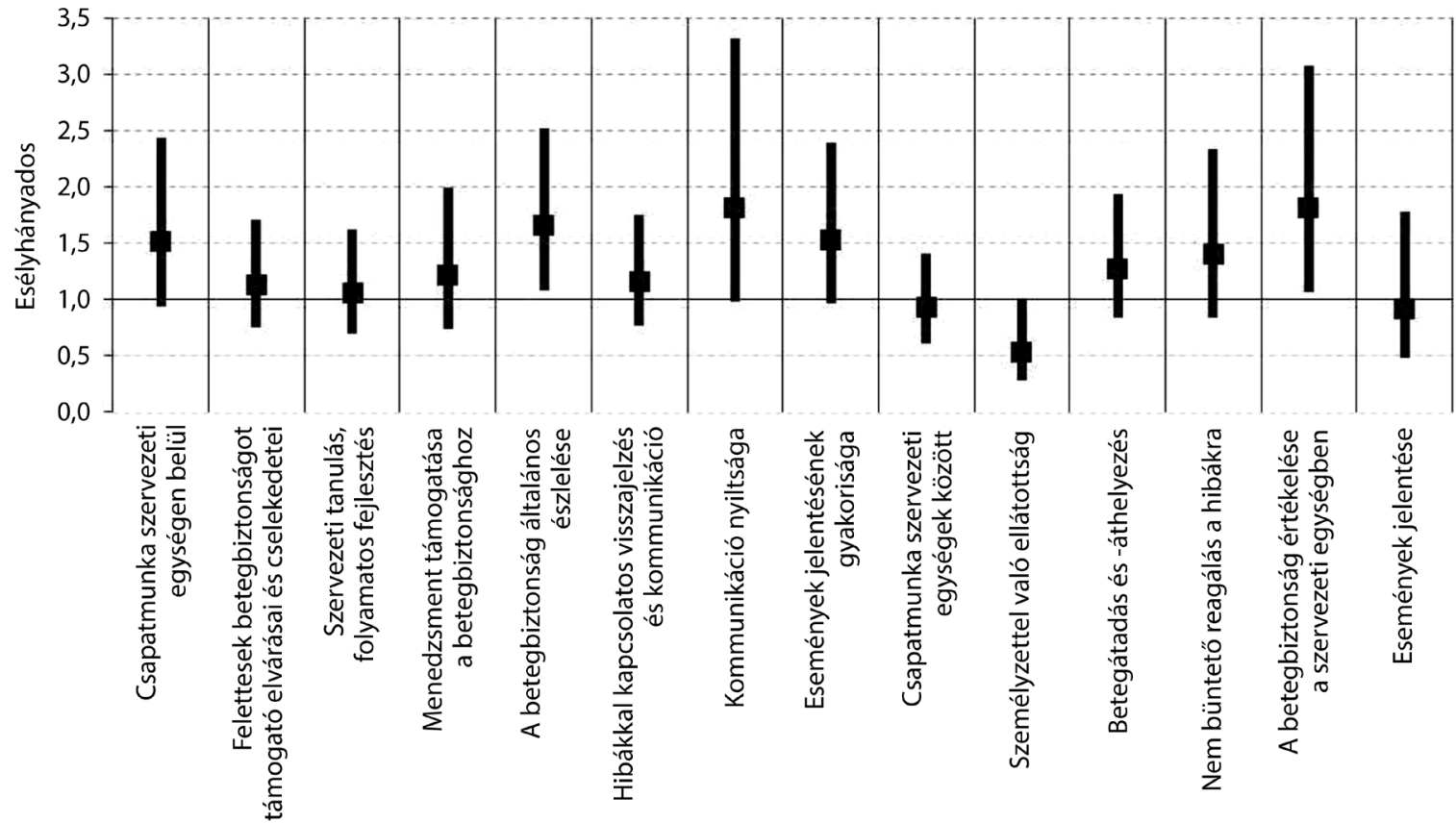

2. ábra | A szervezeti kultúra dimenziókat jellemző változók esélyhányadosai (és 95\%-os CI) az önálló járóbeteg-szakrendelők esetében

mutatók értékei nemzetközi összehasonlításban alacsonynak tekinthetők. Azon dimenziók, amelyek esetében a pozitív válaszok aránya $50 \%$ alatti, fejlesztendő területnek minősülnek [10].

Az akkreditációs program elindulását követően betegbiztonságot támogató szervezeti kultúra kulcstényezőinek megfeleltethető dimenziók közül több megítélése is mindkét intézménytípus esetében pozitív irányba mozdult el, így: a csapatmunka a szervezeti egységben, szervezeti tanulás és folyamatos fejlődés, az általános felfogás a betegbiztonságról szervezeti egységen belül, valamint a nyílt kommunikáció.

A csapatmunka és a betegbiztonság összefüggéseinek feltárására több kutatás is irányult. Manser szisztematikus irodalomelemzésen alapuló áttekintésében rámutatott, hogy a kommunikációs zavarok és a csapatmunkával kapcsolatos kérdések a nemkívánatos események hátterében azonosítható leggyakoribb hozzájáruló tényezők [11]. A csapaton belüli kommunikációs problémák és feszültségek az ellátás folyamán késéseket, eljárási, keze- 
lési hibákat okozhatnak. Kutatások hívják fel azonban a figyelmet arra, hogy az ellátók sok esetben nem ismerik fel a csapatmunka jelentőségét az ellátás menete során [11]. Bizonyítékok állnak rendelkezésre arra vonatkozóan, hogy a csapatmunka és a kommunikáció fejlesztése nemcsak a csapatmunkával kapcsolatos tudatosságot fokozza, hanem a kialakuló hibák számának csökkenéséhez is hozzájárul $[11,12]$. Az akkreditációs pilot során több területről érkező, többféle munkakörbe tartozó munkatárs dolgozott együtt a folyamatok áttekintésében, a változtatási pontok azonosításában és a változások bevezetésében egy csapatként. Az oktatások során többször szóltunk a csapatmunka jelentőségéről, előnyeiről és a kapcsolódó szabályokról. Véleményünk szerint ezek a tényezők is hozzájárulhattak a dimenzió kimutatható javulásához.

A kommunikáció nyíltsága szintén a betegbiztonságot támogató kultúra egyik alapköve. A biztonságos szervezet megteremthetôsége ugyanis jelentős részben múlik azon, hogy a betegellátásban közvetlenül érintett munkatársak meg tudják-e beszélni, vitatni egymás között a nemkívánatos eseményeket, majdnem hibákat vagy a nem biztonságos körülményeket, gyakorlatokat. Azokban a szervezeti kultúrákban, ahol egy nemkívánatos esemény megtörténte után a háttérben meghúzódó okok helyett a felelősöket keresik, természetes, hogy a munkatársak a hibákról a büntetéstől való félelem okán nem beszélnek, még akkor sem, ha a nem biztonságos gyakorlatnak nem volt következménye [13]. Mindez hátráltatja a problémák valós okainak megtalálását, azok megszüntetését, és a hasonló okokból fakadó nemkívánatos események potenciális elhárításának lehetőségét. Az őszinte, nyílt kommunikációt nehezíti az egészségügyi szervezetekre jellemző, erősen hierarchikus viszonyrendszer, amelyben a fiatalabb vagy alacsonyabb beosztású kollégák sokszor nem kommunikálják az általuk érzékelt problémákat, mert félnek, hogy inkompetensnek tünhetnek, megalázhatják, leszidhatják őket [14]. Reader közleményében kifejti, hogy a nyílt kommunikáció hozzájárul a betegellátás céljainak megértéséhez, megvalósításához. Ilyen környezetben a munkatársak bátrabban kérdeznek és mondják el véleményüket. A biztonságos légkör, leadership, csapatmunka, protokollok alkalmazása, a hierarchiaszinteken átívelő őszinte kommunikáció elősegíti a biztonságos ellátást [14].

A BELLA-standardokban a menedzsmenttel foglalkozó standardcsoportban megjelenik a nyílt kommunikáció elvárása a betegellátás biztonságával összefüggő problémák kezelésével kapcsolatban. A standard a betegbiztonságot támogató szervezeti kultúra alapjaira is hatni kíván, mivel megfogalmazza, hogy „az egyszemélyi felelós keresése és büntetése belyett a hibák alapveto" okainak feltárását, a hibákból való tanulást” szükséges előtérbe helyezni [15]. A felkészítő programokban - mind a tanácsadások, mind az oktatások során - nagy hangsúlyt fektettünk az őszinte kommunikáció és nem büntető légkör szerepének hangsúlyozására.
A hibákat és a kockázatokat azonban nem csak felismerni és megbeszélni kell, hanem ahhoz, hogy a későbbiekben meg lehessen ooket előzni, egyéni és szervezeti szinten is le kell vonni a megfelelő tanulságokat és be kell vezetni a szükséges változásokat. A tanuló szervezetekben ismerik és alkalmazzák a hibákból való tanulás módszereit, értékelik a folyamatokat és eredményeket, és szükség szerint módosítják azokat, megosztják az intézményben való jó gyakorlatokat, elismerik a jó teljesítményeket [16]. Ezért is bír nagy jelentőséggel a szervezeti tanulás képességével összefüggő dimenzió javulása.

A pilot időszak alatt az oktatásokon részt vevők megismerték az oki kutatás módszertanát, illetve a standardok által szabályozott folyamatokhoz kapcsolódóan áttekintették az intézményi gyakorlatokat és azonosították azokat a pontokat, amelyek módosítást igényelnek. A módosítások bevezetése további, szervezeten belüli oktatásokkal jár, amely során a szervezet megváltoztatja a korábbi és „megtanulja” az új múködését. A pilot programban részt vevő intézmények a standardokhoz kapcsolódó folyamatok során számos esetben végrehajtották ezt a tanulási folyamatot, amely a dimenzió megítélésének a 2. körben tapasztalt statisztikailag szignifikáns javulásához hozzájárulhatott.

A standardok elvárásai a PDCA-ciklus logikáját követik, amely a bevezetés után is elvárja a szabályozott folyamat rendszeres követését és szükség esetén javítását. A standardok által elvárt folyamatos fejlesztés az intézmény tanulási módszereit és a kultúra ezen dimenzióját egyre érettebbé teszi. Ezáltal a szervezet proaktivitása fokozódik, elősegítve a potenciálisan nem biztonságos gyakorlatok felismerését és azok javítását [16].

Az önálló járóbeteg-szakrendelők esetében a kórházakhoz hasonlóan javult a nyílt kommunikáció dimenzió. Szignifikánsan javultak ezenkívül még az általános felfogás a betegbiztonságról és a betegbiztonság szervezeti egységen belüli értékelése dimenziók. Ezen dimenziókban a kimutatott pozitív elmozdulás arra utalhat, hogy olyan szintú szervezeti változások indultak el a pilot időszak alatt, amelyek már a dolgozók betegbiztonsággal kapcsolatos észleléseit is pozitívan befolyásolták.

Ezek az eredmények azért különösen figyelemfelkeltők, mert ismert tény, hogy a szervezeti kultúra változása lassú folyamat, és az általunk vizsgált egyéves intervallumban még csak kisebb mértékú változtatásokra lehetett alkalma az intézményeknek.

Az intézmények körében két vizsgált dimenzió nyers eredményei mutattak mérsékelt, statisztikailag nem szignifikáns romlást. Ezek közül a személyzettel való ellátottság olyan strukturális, rendszerszintü probléma, amelyre az akkreditációs programnak sajnálatos módon nincsen hatása.

Dolgozatunkban kiemeljük a vezetés szerepét mind a szervezeti kultúra alakulásában, mind a változások bevezetésében. Sammer betegbiztonságot támogató szervezeti kultúra cikkében így fogalmaz: „A biztonságot támogató szervezeti kultúra az intézményi vezetéssel kezdödik.” 
Az elkötelezett vezetők jelenléte kritikus tényező a biztonságot támogató szervezeti kultúra kialakításának sikerében [16]. A szervezeti kultúra átalakítása hosszú folyamat, amelynek során a menedzsmentnek jelentős erőfeszítéseket kell tennie, hogy támogatását, a betegbiztonságot támogató szervezeti kultúra iránti elkötelezettségét folyamatosan érzékeljék a munkatársak. A kutatások eredményei szerint a szervezeti kultúra és a betegbiztonság erősen összefüggnek $[8,15]$. A nyílt, hierarchiaszinteken átívelő kommunikáció, a csapatmunka, a vezetői támogatás mind elősegíti a biztonságos ellátást. Ezért van kiemelkedő jelentősége azoknak a programoknak, módszereknek, amelyek a szervezeti kultúrát eredményesen és hosszú távon tudják befolyásolni. A betegbiztonságot javítani kívánó programok így a rövid távon ható, gyors eredményt hozó intézkedések mellett a szervezeti kultúra befolyásolását is célozzák.

A dimenziónkénti pozitív válaszok arányában ugyan csak párszázalékos változások voltak a pilot időszak egy éve alatt, mégis fontos kiemelni, hogy az elmozdulás iránya alapján kedvező változás indult el a kórházak szervezeti kultúrájának egyes területein a BELLA akkreditációs standardok bevezetésének megkezdését követően. A BELLA programban részt vevő intézményekben megkezdődött egy figyelmet érdemlő folyamat, amelynek továbbfejlődésére, fenntartására megvan az esély az akkreditációs program elindulásával [17]. A szervezeti kultúra átalakulása lassú folyamat. A hatások követésére munkacsoportunk ismételt felmérések segítségével az akkreditáció és szervezeti kultúra kapcsolatának elemzését tervezi a BELLA program elindulását követően is a mélyebb összefüggések feltárása érdekében.

Anyagi támogatás: A közlemény megírása anyagi támogatásban nem részesült.

Szerzői munkamegosztás: L. J.: Irodalomkutatás, kérdőívfordítás, kérdőíves vizsgálat kivitelezése, információk szintetizálása, szövegezés, táblázatok szerkesztése. B. Gy.: Kérdőív-adaptáció, szakmai lektorálás, szövegezés véglegesítése. B. É.: Szakmai lektorálás, statisztikai elemzési szempontok kialakítása, szövegezés összehangolása. M. G.: Statisztikai modellépítés, eredmények számítása, szövegezés véglegesítése. S. C.: Irodalomkutatás, kérdőívfordítás, kérdőíves vizsgálat kivitelezése, szövegezés, ábrák, táblázatok szerkesztése. T. E.: Hatásvizsgálat irányítása és koordinációja, a kérdőíves felmérés koordinációja, kérdőívfordítás, kérdőíves vizsgálat kivitelezése, adatbevitel és adattisztítás irányítása, statisztikai elemzések véglegesítése, információk szintetizálása, szövegezés, ábrák, táblázatok szerkesztése. A cikk végleges változatát valamennyi szerző elolvasta és jóváhagyta.

Érdekeltségek: A szerzők közül B. É., L. J., S. C., T. E. a BELLA akkreditációs rendszer kialakításának és fejlesztésének aktív résztvevői. Jelen vizsgálatukat azonban nem fejlesztői, hanem kutatói nézőpontból végezték.

\section{Köszönetnyilvánítás}

Ezúton fejezzük ki köszönetünket a pilot helyszínek vezetőinek a kutatásunkhoz való csatlakozásért, az intézményi kapcsolattartóinknak a kérdőíves felmérés támogatásáért, és a pilot helyszínek munkatársainak, akik a kérdőív kitöltésével hozzájárultak kutatásunkhoz, valamint Gábri Annamáriának és Gáspár Anettnek az adatok rögzítéséért.

\section{Irodalom}

[1] Bakacsi, Gy.: The basics of organisational behaviour. [A szervezeti magatartás alapjai.] Semmelweis Kiadó, Budapest, 2015. [Hungarian]

[2] Nieva, V. F., Sorra, J.: Safety culture assessment: a tool for improving patient safety in healthcare organizations. Qual. Saf. Health Care, 2003, 12(Suppl. II), iil7-ii23.

[3] Halligan, M., Zecevic, A.: Safety culture in healthcare: a review of concepts, dimensions, measures and progress. BMJ Qual. Saf., 2011, 20(4), 338-343.

[4] Watcher, R. M.: Understanding patient safety. 2nd ed. Lange, New York, 2012.

[5] Scott, T., Mannion, R., Davies, H. T., et al.: Implementing culture change in health care: theory and practice. Int. J. Qual. Health Care, 2003, 15(2), 111-118.

[6] Sorra, J. S., Dyer, N.: Multilevel psychometric properties of the AHRQ hospital survey on patient safety culture. BMC Health Serv. Res., 2010, 10, 199.

[7] AHRQ: Hospital survey on patient safety culture: Items and dimensions. http://www.ahrq.gov/professionals/quality-patientsafety/patientsafetyculture/hospital/userguide/hospdim.html

[8] Research scan: Does improving safety culture affect patient outcomes? The Health Foundation, 2011. http://patientsafety. health.org.uk/sites/default/files/resources/does_improving_ safety_culture_affect_outcomes.pdf

[9] Sorra, J., Gray, L., Streagle, S., et al.: AHRQ Hospital survey on patient safety culture: User's Guide. AHRQ Publication No. 15(16)-0049-EF (Replaces 04-0041). Agency for Healthcare Research and Quality, Rockville, MD, January 2016. http://www.ahrq.gov/sites/default/files/wysiwyg/professionals/quality-patient-safety/patientsafetyculture/hospital/userguide/hospcult.pdf

[10] Santiago, T. H., Turrini, R. N.: Organizational culture and climate for patient safety in intensive care units. Rev. Esc. Enferm. USP, 2015, 49(Esp.), 121-127.

[11] Manser, T.: Teamwork and patient safety in dynamic domains of healthcare: a review of literature. Acta Anaesthesiol. Scand., 2009, 53(2), 143-151.

[12] Barrett, J., Gifford, C., Morey, J., et al.: Enhancing patient safety through teamwork training. J. Healthc. Risk Manag., 2001, 21(4), 57-65.

[13] Bowman, C., Neeman, N., Sehgal, N. L.: Enculturation of unsafe attitudes and behaviors: student perceptions of safety culture. Acad. Med., 2013, 88(6), 802-810.

[14] Reader, T. W., Flin, R., Mearns, K., et al.: Interdisciplinary communication in the intensive care unit. Br. J. Anaesth., 2007, 98(3), 347-352.

[15] Belicza, É. (ed.): The standards of inpatient and outpatient care. [A fekvő- és járóbeteg-ellátás standardjai.] GYEMSZI, Budapest, 2014. [Hungarian]

[16] Sammer, E. C., Lykens, K., Singh, K. P., et al.: What is patient safety culture? A review of the literature. J. Nurs. Scholarsh., 2010, 42(2), 156-165.

[17] Braithwaite, J., Greenfield, D., Westbrook, J., et al.: Health service accreditation as a predictor of clinical and organisational performance: a blinded, random, stratified study. Qual. Saf. Health Care, 2010, 19(1), 14-21.

(Lám Judit dr.,

Budapest, Kútvölgyi út 2., 1125 e-mail: lam@emk.sote.hu) 